\title{
Improvement of nutritional and nutraceutical value of nixtamalized maize tortillas by addition of extruded chia flour
}

\author{
Mejora del valor nutricional y nutracéutico de tortillas de maíz nixtamalizado mediante la adición \\ de harina de chía extrudida
}

Liliana León-López, Cuauhtémoc Reyes-Moreno, Alfa Hatzue Ley-Osuna, Janitzio Xiomara Korina Perales-Sánchez, Jorge Milán-Carrillo, Edith Oliva Cuevas-Rodríguez, Roberto Gutiérrez-Dorado*

Facultad de Ciencias Químico Biológicas, Universidad Autónoma de Sinaloa, AP 1354, CP 80,000 Culiacán, Sinaloa, México.

\section{ABSTRACT}

In this work the objectives were: (1) To optimize the extrusion conditions of defatted chia seeds maximizing antioxidant activity (AoxA), total phenolic content (TPC) and in vitro protein digestibility (IVPD), and (2) To evaluate the nutritional, nutraceutical, and sensory (acceptability) properties of tortillas formulated with commercial nixtamalized maize flour (MASECAMR) and optimized extruded defatted chia flour. Response surface methodology was applied as an optimization tool. A central composite rotatable design with two factors [Extrusion temperature $\left(E T=50-160^{\circ} \mathrm{C}\right)$, screw speed $(S S=50-240 \mathrm{rpm})]$ in five levels were used. The extruded from each treatment (13) were dried and ground to obtain extruded defatted chia flours (EDCF). The desirability function was applied as optimization technique. The prediction models for each response variable were adequate and reproducible. The optimal extrusion conditions to obtain optimized extruded defatted chia flour (OEDCF) were $E T=147^{\circ} \mathrm{C} / \mathrm{SS}=237 \mathrm{rpm}$; a high global desirability $(\boldsymbol{D}=0.815)$ was associated with these optimal conditions. The tortillas elaborated with MASECA ${ }^{\mathrm{TM}}$ flour + OEDCF had higher IVPD, C-PER, TPC and AoxA, and better antihypertensive potential than elaborated with only $M_{\text {MSECA }}^{\text {TM }}$ flour. The addition of OEDCF to MASECA ${ }^{\mathrm{TM}}$ flour increased the nutritional and nutraceutical value of the tortillas.

Keywords: Tortillas, chia, extrusion, optimization, antioxidant/ antihypertensive activity.

\section{RESUMEN}

En este trabajo los objetivos fueron: (1) Optimizar condiciones de extrusión para semillas de chía desgrasada maximizando actividad antioxidante (AAox), compuestos fenólicos totales (CFT) y digestibilidad proteínica in vitro (DPIV), y (2) Evaluar propiedades nutricionales, nutracéuticas y sensoriales (aceptabilidad) de tortillas formuladas con harinas de maíz nixtamalizado comercial (MASECAMR) y chía desgrasada extrudida optimizada. Se aplicó metodología de superficie de respuesta como herramienta de optimización. Se utilizó diseño central compuesto rotable con dos factores [Temperatura de extrusión $\left(T E=50-160^{\circ} \mathrm{C}\right)$ / Velocidad del tornillo (VT=50-240 rpm)] y cinco niveles. Los extrudidos de cada tratamiento (13) se secaron y molturaron para obtener harinas de chía desgrasada extrudida $(H C D E)$. Como técnica de optimización se aplicó la función de deseabilidad. Los modelos de predicción para cada variable de respuesta fueron adecuados y reproducibles. Las condiciones óptimas de extrusión para obtener harina de chía desgrasada extrudida optimizada ( $H C D E O)$ fueron: $T E=147^{\circ} \mathrm{C} / V T=237 \mathrm{rpm}$; la deseabilidad global $(D=0.815)$ asociada con estas condiciones óptimas fue alta. Las tortillas elaboradas con harina MASECA $^{\mathrm{MR}}+\mathrm{HCDEO}$ tuvieron mayor DPIV, C-PER, CFT, AAox y mejor potencial antihipertensivo que elaboradas solo con harina MASECA ${ }^{\mathrm{MR}}$. La adición de HCDEO a la harina MASECAMR incrementó el valor nutricional/nutracéutico de las tortillas.

Palabras claves: Tortillas, chía, extrusión, optimización, actividad antioxidante/antihipertensiva.

\section{INTRODUCTION}

In México, especially among low socioeconomic groups, maize tortillas, wheat flour tortillas, and table bread are the basic cereal foods of the diet. Maize-based tortillas and wheat-based bakery items lack the EAA lysine as well as optimum levels of relevant micronutrients such as iron, zinc, and vitamins A, D, E, and $B_{12}$ (Amaya-Guerra et al., 2004; Chuck-Hernández et al., 2015). Some researchers have reported improvements in tortilla quality by increasing nutritional, nutraceutical, and sensorial properties throughout the addition of several kind of flours: common bean-amaranth (Vázquez-Rodríguez et al., 2013), oat (Cortes-Soriano et al., 2016), soybean (Acevedo-Pacheco and Serna-Saldívar, 2016), common bean (Grajales-García et al., 2012; Treviño-Mejía et al., 2016).The fortification of maize tortillas with chia flour also represents an alternative of nutritional and nutraceutical improvement for this product. Rendón-Villalobos et al. (2012), are the only researchers who have reported the elaboration of tortillas from nixtamalized maize flour added with chia flour. In that research, they evaluated the effect of only raw chia flour supplementation on the physicochemical and sensorial properties, as well as starch digestibility of tortillas. They mentioned that these tortillas can be considered as a nutraceutical food, due to the increase in the total dietary fiber and the decrease in the predicted glycemic index. However, in that research work, the improvement in the nutraceutical quality, related to the phenolic compounds content and the antioxidant activity, as well as the nutritional quality, were not studied.

*Autor para correspondencia: Roberto Gutiérrez-Dorado Correo electrónico: robe399@hotmail.com

Recibido: 11 de noviembre de 2018 Aceptado: 13 de marzo de 2019 
Mayas and Aztec used Chia (Salvia hispanica L) seeds, as medical food 3,500 years B.C. These seeds have good protein (15-25\%), lipids (29-34\% of which $35-64 \%$ a-Linolenic acid and 17-35\% Linoleic acid), carbohydrates (26-41\%), and dietary fiber (18-40\%) content (Ullah et al., 2015; Bochicchio et al., 2015). Chia seeds are also rich in phenolic compounds and have a high antioxidant capacity. The most commonly polyphenols responsible for antioxidant activity are flavonoids and phenolic acids (phenolic acids: rosmarinic, chlorogenic, protocatechuic, gallic, ferulic and caffeic acids; flavonols: myricetin, quercetin and kaempferol; isoflavones: genistin, genistein, daidzin, daidzein, glycitin and glycitein) (Martínez-Cruz and Paredes-López, 2014; Bochicchio et al., 2015; Valdivia-López and Tecante, 2015). In addition to antioxidant activity, the dietary polyphenols also have several beneficial biological activities as such anti-allergic, anti-inflammatory, anti-hypertensive, anti-mutagenic, antidiabetic, anti-carcinogenic, among others (Ullah et al., 2015; Orona-Tamayo et al., 2016). Numerous methods are used to evaluate antioxidant activities of natural compounds in foods or biological systems with varying results. Due to its good repeatability and simplicity to perform, the three most frequently methods used to assess in vitro antioxidant activity are ABTS, DPPH, and ORAC. The advantage of the ORAC method over ABTS and DPPH is that it is automated and largely standardized; hence, values can be easily compared among laboratories. In addition, the ORAC method is reported to mimic phenols antioxidant activity in biological systems, better than other methods, since it uses biologically relevant free radicals and integrates both time and degree of activity of antioxidants. However, the method often requires the use of expensive equipment (Awika et al., 2003). These assays have been employed to evaluate antioxidant activity in maize and chia (Mora-Rochín et al., 2010; Grajales-García et al., 2012; Martínez-Cruz and Paredes-López, 2014; ValdiviaLópez and Tecante, 2015; Espinoza-Moreno et al., 2016; Orona-Tamayo et al., 2016; Gómez-Favela et al., 2017; ReyesMoreno et al., 2018; Argüelles-López et al., 2018).

Reyes-Moreno et al. (2018) reported that, the extrusion process is an adequate technology to generate functional foods. This process increases the digestibility and biological value of proteins, and maintains or increases the content of bioactive compounds and nutraceutical properties of foods, due to the use of high-temperature, high-pressure, and high shear conditions in a short period. These accelerate process conditions, used during the extrusion, cause important molecular transformation and chemical reactions (modification in starch, proteins, dietary fiber and lipids, inactivation of enzymes and microorganisms, and formation of color polymers and volatile flavor components) on the food materials. In addition, this process is a highly efficient alternative technology that minimizes energy and water consumption, and does not produce polluting effluents (Reyes-Moreno et al., 2018).

Due to the above mentioned, it could be said that the addition of flours elaborated from promising materials as chia, processed with efficient alternative technologies as extrusion, are a viable option to improve the nutritional and nutraceutical quality of tortillas made from nixtamalized maize flours. For this reason, the objectives in this research were to find the optimum extrusion conditions of defatted chia seeds that would maximize antioxidant activity (AoxA), total phenolic content (TPC), and in vitro protein digestibility (IVPD), and evaluate the nutritional, nutraceutical and sensory (acceptability) properties of tortillas formulated with commercial nixtamalized maize flour (MASECA ${ }^{\mathrm{TM}}$ ) and optimized extruded defatted chia flour.

\section{MATERIALS AND METHODS Materials}

Whole chia seeds obtained in a market of the locality (Mercado Rafael Buelna, Culiacán, Sinaloa, México) were used as materials of the study.

\section{Methods \\ Production of extruded defatted chia flours (EDCF)}

Chia seeds lots $(500 \mathrm{~g})$ were defatted using an oil extractor press (model DL-ZYJ05). Pellets of defatted chia were placed in a domestic blender at high velocity to obtain meals that passed through an 40-US mesh $(0.425 \mathrm{~mm})$ screen, which were mixed with lime $(0.21 \mathrm{~g} / 100 \mathrm{~g}$ meal) and water to achieve a water content of $28 \mathrm{~g} / 100 \mathrm{~g}$, and then packed in polyethylene bags and stored for $12 \mathrm{~h}$ at $4^{\circ} \mathrm{C}$. Before extrusion, samples were tempered at $25^{\circ} \mathrm{C}$ for one hour. The extrusion experiments were carried out on Model 20 DN single-screw laboratory extruder (CW Brabender Instruments, Inc, NJ, USA) with a $19 \mathrm{~mm}$ screw-diameter, length-to-diameter 20:1; nominal compression ratio 1:1, and die to open of $5 \mathrm{~mm}$. A screw-operated feed hopper fed the extruder at a feed screw of $30 \mathrm{rpm}$ (fed rate was $70 \mathrm{~g} / \mathrm{min}$ ). Extrudates were cooled and dried at environmental conditions $\left(25^{\circ} \mathrm{C}, \mathrm{RH}=65 \%\right)$ and milled (UD Cyclone Sample Mill, UD Corp, Boulder, CO, USA) to pass through an 80 -US mesh $(0.180 \mathrm{~mm})$ screen, packed in plastic bags, and stored at $4^{\circ} \mathrm{C}$.

\section{Extraction of free and bound phenolic compounds}

A flour sample $(0.5 \mathrm{~g})$ was mixed with $10 \mathrm{~mL}$ of ethanol $(80 \%, \mathrm{v} / \mathrm{v})$, agitated (50 rpm/10 min), and centrifuged (3000×g, $10 \mathrm{~min}$ ). This extraction step was performed two more times. The recovered supernatant was vacuum evaporated to obtain the free phenolic compound. The pellet was hydrolyzed with $10 \mathrm{~mL}$ of sodium hydroxide $(2 \mathrm{M})$ first at $95^{\circ} \mathrm{C}$ for $30 \mathrm{~min}$, and then at $25^{\circ} \mathrm{C}$ by $60 \mathrm{~min}$, using a water bath with agitation ( $60 \mathrm{rpm})$. Then, it was neutralized with chloride acid, followed by lipid removal with hexane. The bound phenolic compounds were extracted with $10 \mathrm{~mL}$ of ethyl acetate, repeating the extraction step four more times. Finally, extracts were vacuum evaporated and stored at -20 ${ }^{\circ} \mathrm{C}$ (Salas-López et al., 2018).

\section{Antioxidant activity (AoxA) and total phenolic content (TPC)}

The ABTS assay was performed diluting free and bound 
extracts with ethanol. Aliquots of $20 \mu \mathrm{L}$ of each dilution were taken and mixed with $2.0 \mathrm{~mL}$ of diluted radical cation ABTS-+, and 6 minutes later the absorbance was determined at 734 $\mathrm{nm}$ in a UV-visible spectrophotometer (GENESYS 10UV, Thermo electron, Inc, Madison, WI, USA) (Re et al., 1999). To carry out the ORAC assay, free and bound phenolic extracts were diluted in $75 \mathrm{mM}$ phosphate buffer ( $\mathrm{pH} 7.4)$. Aliquots of 25 $\mu \mathrm{L}$ of diluted extracts were mixed with $150 \mathrm{~mL}$ of fluorescein $(0.1 \mathrm{mM})$ and $25 \mu \mathrm{L}$ of the peroxyl radical AAPH (200 mM). After 30 minutes, fluorescence $(485 \mathrm{~nm}$ for excitation and $538 \mathrm{~nm}$ for emission) was measured $\left(37^{\circ} \mathrm{C}\right)$ at 2 min intervals for 60 min, using a Synergy Microplate Reader (Synergy ${ }^{\mathrm{TM}}$ HT Multi-Detection, BioTek, Inc., Winooski, VT) (Mora-Rochín et al., 2010). The results of ABTS and ORAC assays are expressed as micromol of Trolox equivalent (TE) per $100 \mathrm{~g}$ of dry weight sample. The TPC of free and bound extracts was determined using $20 \mathrm{~mL}$ of appropriate dilutions of extracts, oxidized with $180 \mathrm{~mL}$ of Folin-Ciocalteu reagent. After 20 min, absorbance of the resulting blue color was measured at $750 \mathrm{~nm}$ using the Synergy Microplate Reader. TPC is expressed as mg of gallic acid equivalent (GAE) / $100 \mathrm{~g}$ of dry weight sample (Espinoza-Moreno et al., 2016). All measurements were carried out in triplicate.

\section{In vitro protein digestibility (IVPD)}

The IVPD was evaluated in EDCF according to SalasLópez et al. (2018). Five milliliters of a multi-enzyme solution [pancreatic trypsin, bovine pancreatic chymotrypsin, porcine intestinal peptidase and distilled water, $\mathrm{pH}=8.0$ ] were mixed with $50 \mathrm{~mL}$ of the protein suspension $(6.25 \mathrm{~g}$ of protein/L,
$\mathrm{pH}=8.0$ ) employing constant stirring in a water bath at $37^{\circ} \mathrm{C}$. The $\mathrm{pH}$ was measured after $10 \mathrm{~min}$, and the following equation used to evaluate IVPD:

$$
\text { IVPD }=210.46-18.10 \mathrm{X}
$$

where $\mathrm{X}=\mathrm{pH}$ after $10 \mathrm{~min}$. The $\mathrm{pH}$ assay was carried out in triplicate.

\section{Optimization using Response surface methodology (RSM)}

To optimization of extrusion condition, we used a central composite experimental design. The employed factors were extrusion temperature $\left(X_{1}=E T=50-160^{\circ} \mathrm{C}\right)$ and screw speed $\left(X_{2}=S S=50-240 \mathrm{rpm}\right)$, and the analyzed responses were antioxidant activity (AoxA), total phenolic content (TPC) and in vitro protein digestibility (IVPD) (Table 1). We applied the stepwise regression procedure to obtain reproducible prediction models (second-order polynomial) to each response variable, and the desirability numeric method of the $R S M$ to determine the best combination of extrusion process variables $(E T, S S)$. The fitted models for dependent variables were evaluated at any point $X=(X 1, X 2)$ of the experimental zone, where each model predicted response variable values, $\hat{\mathrm{Y}} 1(\mathrm{X}), \hat{\mathrm{Y}} 2(\mathrm{X})$ and $\hat{\mathrm{Y}} 3(\mathrm{X})$. Each $\hat{\mathrm{Y}} \mathrm{i}(\mathrm{X})$ was transformed into a value $\operatorname{di}(X)$, which fells in the range $(0,1)$ and measured the desirability degree of the response in reference to the optimum value intended to be reached. In this case, the highest possible of AoxA, TPC, and IVPD values was searched. The multi-response global desirability $(D)$ was determined from the individual desirabilities with the mathematical function $D=\left(d_{1} d_{2} d_{3}\right)^{1 / 3}$, where the ideal optimum value is $D=1$; an ac-

Table 1. Combination of extrusion process variable used to produce extruded defatted chia flours, and experimental result of response variable of each one treatment flours.

Tabla 1. Combinación de variables del proceso de extrusión utilizadas para producir harinas de chía desgrasada extrudida y resultados de las variables de respuesta de cada uno de los tratamientos.

\begin{tabular}{|c|c|c|c|c|c|}
\hline \multirow[t]{2}{*}{ Treat } & \multicolumn{2}{|c|}{ Process variables } & \multicolumn{3}{|c|}{ Response variable } \\
\hline & $\begin{array}{l}\text { Extrusion temperature } \\
\qquad\left({ }^{\circ} \mathrm{C}\right)\end{array}$ & $\begin{array}{l}\text { Screw speed } \\
\quad(\text { rpm })\end{array}$ & AoxA $^{2}$ & TPC $^{3}$ & IVDP $^{4}$ \\
\hline 1 & 66.11 & 77.82 & 18,131 & 526.68 & 81.83 \\
\hline 2 & 143.89 & 77.82 & 22,613 & 561.58 & 84.56 \\
\hline 3 & 66.11 & 212.18 & 21,572 & 551.78 & 81.48 \\
\hline 4 & 143.89 & 212.18 & 24,968 & 575.06 & 83.56 \\
\hline 5 & 50.00 & 145.00 & 18,629 & 541.99 & 80.92 \\
\hline 6 & 160.00 & 145.00 & 23,483 & 597.54 & 84.43 \\
\hline 7 & 105.00 & 50.00 & 24,443 & 541.42 & 84.94 \\
\hline 8 & 105.00 & 240.00 & 28,949 & 558.60 & 84.06 \\
\hline 9 & 105.00 & 145.00 & 26,910 & 573.33 & 82.23 \\
\hline 10 & 105.00 & 145.00 & 26,196 & 577.93 & 81.22 \\
\hline 11 & 105.00 & 145.00 & 25,883 & 568.19 & 82.84 \\
\hline 12 & 105.00 & 145.00 & 24,318 & 564.10 & 81.99 \\
\hline 13 & 105.00 & 145.00 & 25,107 & 581.56 & 81.66 \\
\hline
\end{tabular}

${ }^{1}$ Rotable central composite experimental design with two factors and five levels (13 assays), ${ }^{2} A o x A=$ Antioxidant activity [ $\mu$ mol Trolox equivalents (TE) / $100 \mathrm{~g}$ sample, DW], ${ }^{3}$ TPC $=$ Total phenolic compounds [mg Gallic acid equivalents (GAE) $/ 100 \mathrm{~g}$ sample, DW], ${ }^{4} / V P D=$ In vitro protein digestibility (\%) 
ceptable value for $D$ can be between 0.6 and 0.8. The RSM analyzed was realized using the software Design Expert version 7.0.0 (Stat-Ease, Minneapolis, MN, USA).

\section{Chemical composition, soluble and insoluble dietary fiber (SDF/IDF) of the optimized extruded defatted chia flour (OEDCF)}

Protein (Nx6.25), lipids, and moisture contents were determinate according to official AOAC (1999) methods 960.52, 920.39C, 925.09B, respectively. To determine SDF and IDF, the official AOAC (1999) 985.29 method and the TDF assay kit from Sigma-Aldrich (TDF 100 A) were used.

Nutritional properties: Essential amino acid (EAA), in vitro protein digestibility (IVPD), chemical score (CS) and calculated protein efficiency ratio (C-PER) of the OEDCF

The nutritional properties (EAA, IVPD, CS and C-PER) of the OEDCF were determined according to Salas-López et al. (2018). EAA composition was determined using an analytical scale $(4.6 \mathrm{~mm} \times 250 \mathrm{~mm}$ ) hypersil ODS C18 column (SGE, Dandenong, Australia) kept at $38{ }^{\circ} \mathrm{C}$ and connected to an HPLC system (GBC, Dandenong, Australia) equipped with a fluorescence detector $>$ LC 5100 set at 270 and $316 \mathrm{~nm}$ for excitation and emission, respectively. Using an ultraviolet detector at $280 \mathrm{~nm}$ the tryptophan was detected. The IVPD was evaluated using a multi-enzyme system, above described. The chemical score (CS) was calculated as follows: $C S=$ (Content of the most limiting $E A A / R E A A R) \times 100$; where $E A A$ is the essential amino acid and REAAR is the recommended amino acid requirements for three years old children and older, adolescents, and adults (FAO, 2013). C-PER was calculated based on the IVPD and the EAA composition of the sample. All determinations carried out in triplicate.

\section{Antihypertensive potential $\left(I C_{50}\right)$ of the OEDCF}

The ACE (angiotensin converting enzyme) inhibitory activity in free and bound phenolic extracts was determined using the Dojindo ACE Kit-WST test kit (Dojindo Laboratories, Kumamoto, Japan). This method is based on the colorimetric detection of an indicator after a redox reaction, where the absorbance (Abs) at $450 \mathrm{~nm}$ was measured using a Microplate Reader (Synergy ${ }^{\mathrm{TM}} \mathrm{HT}$ Multi-Detection, BioTek, Inc., Winooski, VT, USA). The $I C_{50}$ (concentration of phenolic extract that caused an inhibition of $50 \%$ in the ACE activity) values were calculated from different concentrations of the phenolic extracts and $A C E$ inhibitory activity values using the Prism v5 software (GraphPad Prism) (Argüelles-López et al., 2018).

\section{Quality evaluation of tortillas elaborated from OEDCF}

Tortillas were elaborated from the flour mixture of $75 \%$ MASECA ${ }^{\text {TM }}$ flour $+25 \%$ OEDCF; tortillas made with MASECA ${ }^{\mathrm{TM}}$ were used as control. The tortillas were prepared with water at $30^{\circ} \mathrm{C}$ until obtaining an adequate consistency (Corrales-Bañuelos et al., 2016). Tortillas' puffing was evaluated throughout their cooking using a 1 to 3 scale, where: $1=$ tortillas with no puffing, $2=$ tortillas with an intermediate puffing, and $3=$ tortillas with a complete puffing (Milán-Carrillo et al., 2006). The tortilla rollability was performed $30 \mathrm{~min}$ after elaboration; these were rolled in a glass stick of $2.54 \mathrm{~cm}$ of diameter, and the degree of breakage of tortilla surface (0$100 \%$ ) indicated the rollability (1-5) as follows: $0 \%=1,25 \%=2$, $50 \%=3,75 \%=4$ and $100 \%=5$ (Bedolla and Rooney, 1984). For sensory evaluation of tortillas, squared pieces pre-heated at $45^{\circ} \mathrm{C}$ were presented in one plate to taste. The testing panel was composed of 120 consumers (aged between 18 and 35 years of age) who were habitual tortilla consumers. Plain water was used as a palate cleanser between samples. Consumers assessed the flavor, odor, color, texture and general acceptance. The consumers were asked to indicate his/her degree of liking/disliking using a 9-category hedonic scale ( 1 = dislike extremely to $9=$ like extremely). To determine chemical composition, as well as nutritional and nutraceutical properties of tortillas, samples were dried and milled to pass through an 80 -US mesh $(0.180 \mathrm{~mm})$ sieve and packed in plastic bags.

\section{Statistical analyses of OEDCF and tortillas properties}

One-way ANOVA and Duncan's multiple range test for means comparisons were applied to the result of the evaluated properties in $O E D C F$, unprocessed defatted chia flour (UDCF), and tortillas using a $5 \%$ of significance level.

\section{RESULTS AND DISCUSSION}

Optimal conditions for defatted chia flour extrusion Prediction models for response variables

The experimental values for AoxA, TPC, and IVPD varied from 18,131 to $28,949 \mu \mathrm{mol}$ TE / 100g sample (DW), from 526.68 to $581.56 \mathrm{mg} \mathrm{GAE} / 100 \mathrm{~g}$ sample (DW), and from 80.92 to $84.94 \%$ (DW), respectively (Table 1 ).

\section{Antioxidant activity (AoxA)}

ANOVA showed that the AoxA of the EDCF depended significantly $(p<0.05)$ on linear terms of extrusion temperature $\left[E T\left(X_{1}\right)\right]$ and screw speed $\left[S S\left(X_{2}\right)\right]$, as well as the extrusion temperature quadratic term $\left[(E T)^{2}\right](p<0.0001)$. The prediction models for AoxA of the EDCF were:

Coded variables:

$Y_{\text {AoxA }}=25,676.63+1,842.86\left(X_{1}\right)+1,522.86\left(X_{2}\right)-2,825.46\left(X_{1}\right)^{2}$

Uncoded variables:

AoxA $=-3,181.49+439.68(E T)+22.67(S S)-1.86(E T)^{2}$

This prediction model explained $88.8 \%$ of the total variability ( $p=0.0001$ ) of the values of AoxA of the EDCF. The lack of fit test was non-significant ( $p=0.2987$ ). It was found that the relative dispersion of the experimental points from the models (CV) predictions was $<10 \%$. The process variables $(E T, S S)$ had a significant effect on the behavior of the AoxA in its linear terms for both, as well as the quadratic term of $E T$ (Fig 1A). The lowest value of AoxA $(15,286 \mu \mathrm{mol}$ TE/100 g) was located at $E T=50^{\circ} \mathrm{C} / S S=50 \mathrm{rpm}$. In addition, we observed that increasing SS increased AoxA, while this response also increased with $E T$ to reach a maximum about $117^{\circ} \mathrm{C}$ and then there was a decrease in AoxA. The desirable highest value of 


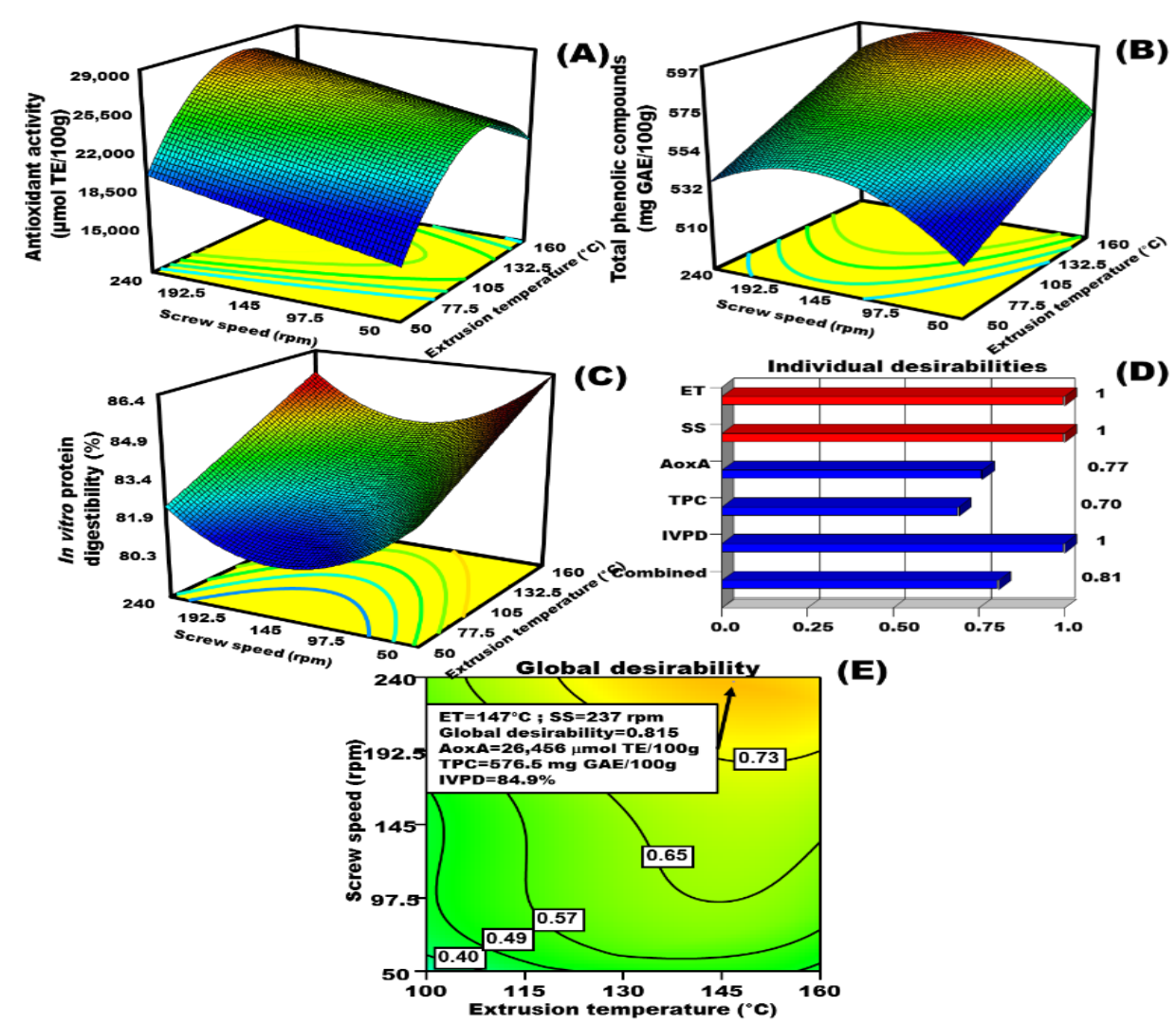

Fig 1. Response Surface plots showing the effect of extrusion temperature and screw speed on: A) Antioxidant activity (AoxA), (B) Total phenolic compounds (TPC); and (C) In vitro protein digestibility (IVPD). (D) Individual desirabilities for AoxA, TPC and IVPD. (E) Global desirability plot showing the region with the best combination of extrusion process variable for producing optimized extruded defatted chia flour (OEDCF). Fig 1. Gráficas de superficie de respuesta mostrando el efecto de la temperatura de extrusión y velocidad de tornillo sobre (A) Actividad antioxidante (AAox), Compuestos fenólicos totales (CFT) y (C) Digestibilidad proteínica in vitro (DPIV). (D) Deseabilidades individuales para AAox, CFT y DPIV, (E) Gráfico de deseabilidad global que muestra la región con la mejor combinación de variables de proceso de extrusión para producir harina de chía desgrasada extrudida optimizada (HCDEO).

AoxA $(28,114 \mu \mathrm{mol} \mathrm{TE} / 100 \mathrm{~g})$ was located at $E T=117^{\circ} \mathrm{C} / \mathrm{SS}=$ $239 \mathrm{rpm}$.

In general, heat treatments are thought to be the primary cause of a decrease in natural antioxidants content (Kaur and Kapoor, 2001). However, different researchers have reported increases in AoxA in extruded products, due to the release and generation of antioxidant compounds, as well as the inactivation of enzymes responsible for the oxidation of this type of compounds (Milán-Carrillo et al., 2012; Espinoza-Moreno et al., 2016). Korus et al. (2007) reported a decrease in antioxidant activity and polyphenols content during the extrusion of common bean and a bean/maize mixture, respectively, mainly attributed to the process conditions. They did not perform the optimization of the extrusion process. The potential of chia seeds as functional food has been related to their antioxidant activity and other nutraceutical properties (hypocholesterolemic, anti-hypertensive) (Salazar-Vega et al., 2012; Orona-Tamayo et al., 2016).

\section{Total phenolic content (TPC)}

ANOVA showed a significant quadratic model $(p<$ $0.0001)$ for TPC. This analysis also showed that the TPC con- tent of the EDCF was significantly depended both on the linear terms of the extrusion temperature $(E T)(p<0.0001)$ and the screw speed (SS) $(p=0.0122)$, as well as the quadratic screw speed term $(S S)^{2}$. The prediction models for the TPC of the $E D C F$ were:

Coded variables:

$Y_{T P C}=570.83+17.09\left(X_{1}\right)+7.86\left(X_{2}\right)-12.62\left(X_{2}\right)^{2}$

Uncoded variables:

$T P C=448.91+0.4394(E T)+0.9281$ (SS) $-2.7969 E^{-3}(S S)^{2}$

This prediction model explained $89.69 \%$ of the total variability $(\mathrm{p}<0.0001)$ of the TPC values of the EDCF. The adjusted determination coefficient $R^{2}$ of the model was 0.8625 , and the lack of adjustment was non-significant $(p=0.5059)$. Furthermore, the relative dispersion of the experimental points concerning the predicted values with the model (CV) was $1.26 \%$. These values indicate that the experimental model for the TPC of the EDCF was adequate and reproducible.

The lowest TPC value $(510 \mathrm{mg}$ GAE/100 g, DW) reached, was at $E T=50^{\circ} \mathrm{C} / S S=50 \mathrm{rpm}$. The desirable highest value (596 mg GAE/100 g, DW) of TPC was observed at top 
$E T$ and intermediate $S S\left(E T=160^{\circ} \mathrm{C} / S S=165 \mathrm{rpm}\right)$. According to some researchers, as Hirth et al. (2015), increasing the SS during the extrusion process, the residence time can decrease by up to $50 \%$; less processing time may result in higher retention of thermolabile compounds, such as some phenolic compounds. However, an increase in SS also produces an increase in the specific extruder mechanical energy, with a consequent increment in temperature inside the extruder barrel. This temperature increase could affect the retention of thermolabile compounds in the processed material, although the processing time is shorter. These behaviors are shown in Fig 1B. As the SS increases the TPC content also increases, however, by exceeding $145 \mathrm{rpm}$, a decrease in the TPC levels is evident, which is attributed to the increase in temperature associated to an increased cutting effort produced by a higher SS.

Sarawong et al. (2014) suggest that the disruption of phenolic compounds attached to the matrix of the cell wall by the high-temperature effect, during the extrusion process, translates into the increased release of bound phenolic compounds; in Fig 1B it is observed that by increasing the $E T$ the content of TPC also increases.

\section{In vitro protein digestibility (IVPD)}

ANOVA showed a significant quadratic model $(p=$ 0.0002 ) for IVPD. This analysis also showed that the IVPD of the EDCF depended significantly both on the linear terms of the extrusion temperature (ET) and the screw speed (SS), as the quadratic term of screw speed $(S S)^{2}$. The prediction model for IVPD of the EDCF were:

Coded variables:

$Y_{\text {NPDD }}=82.10+1.22\left(X_{1}\right)-0.32\left(X_{2}\right)+1.05\left(X_{2}\right)^{2}$

Uncoded variables:

IVPD $=84.40+0.0314(E T)-0.0725(S S)+2.333 E^{-4}(S S)^{2}$

This prediction model explained $87.88 \%$ of the total variability $(p=0.0002)$ of the IVPD values of the EDCF. The adjusted determination coefficient $R^{2}$ of the model was 0.8385 , and the lack of fit test was non-significant $(p=0.6355)$. In addition, the relative dispersion of the experimental points concerning the predicted values with the model (CV) was $0.68 \%$. These values indicate that the experimental model for the IVPD of the EDCF was adequate and reproducible. Fig $1 C$ shows that both process variables $(E T, S S)$ had a significant effect on the behavior of IVPD. The lowest value (80.35\%) of $I V P D$ was located at $E T=50^{\circ} \mathrm{C} / S S=156 \mathrm{rpm}$. Two desirable highest values ( 85.5 and $86.4 \%$ ) of IVPD can be observed; they correspond to the highest $E T\left(160^{\circ} \mathrm{C}\right)$ and to the highest and lowest values of SS ( 240 and $50 \mathrm{rpm}$, respectively) (Fig 1C).

\section{Optimization of the defatted chia flour extrusion process}

Figure $1 \mathrm{E}$ shows the global desirability $(D)$ as a function of the extrusion process variables $E T$ and SS. D was obtained as the geometric average of the individual desirabilities of each one of the response variables. It was utilized to determine the best combination of process variables (optimum con- ditions) for the production of optimized extruded defatted chia flour (OEDCF) with high values of AoxA, TPC, and IVPD. The optimum extrusion conditions were $E T=147^{\circ} \mathrm{C}$ and $S S=$ $237 \mathrm{rpm}$ showing a global desirability of $D=0.815$ (Fig 1E); the individual desirabilities of the response variables associated with " $D$ " were $d_{A O X A}=0.77, d_{T P C}=0.70$, and $d_{I V P D}=1.00$. Using the ETISS extrusion optimized condition the software predicted values of $26,456 \mu \mathrm{mol}$ Trolox equivalents (TE) / $100 \mathrm{~g}$ sample (DW), $576.5 \mathrm{mg}$ gallic acid equivalents (GAE) / 100g sample (DW), and $84.9 \%$ for AoxA, TPC and IVPD, respectively. OEDCF was produced applying the best combination of extrusion process variables. The experimental values of AoxA, TPC (Table 3), and IVPD (Table 2) of OEDCF were similar to the predicted values, above mentioned, indicating that the optimal conditions of extrusion process were appropriated and reproducible.

Table 2. Chemical composition and essential amino acid content in unprocessed and extruded defatted chia flours.

Tabla 2. Composición química y contenido de aminoácidos esenciales en harinas de chía desgrasadas sin procesar y extrudida.

\begin{tabular}{|c|c|c|c|}
\hline Property & $\begin{array}{c}\text { Unprocessed } \\
\text { defatted chia } \\
\text { flour } \\
\text { (UDCF) }\end{array}$ & $\begin{array}{c}\text { Optimized } \\
\text { extruded } \\
\text { defatted } \\
\text { chia flour } \\
\text { (OEDCF) }\end{array}$ & $\begin{array}{c}\mathrm{FAO}^{1} \\
\text { requirements }\end{array}$ \\
\hline \multicolumn{4}{|c|}{ Chemical composition (\%, DW) } \\
\hline Proteins & $31.09 \pm 0.37^{A}$ & $30.66 \pm 0.29^{A}$ & \\
\hline Lipids & $5.27 \pm 0.06^{A}$ & $5.12 \pm 0.07^{\mathrm{B}}$ & \\
\hline Minerals & $6.88 \pm 0.07^{A}$ & $6.91 \pm 0.08^{A}$ & \\
\hline \multicolumn{4}{|l|}{ Dietary fiber } \\
\hline Soluble & $6.71 \pm 0.09^{B}$ & $7.36 \pm 0.09^{A}$ & \\
\hline Insoluble & $41.21 \pm 0.13^{B}$ & $43.01 \pm 0.13^{A}$ & \\
\hline Total & $47.92 \pm 0.27^{B}$ & $50.37 \pm 0.27^{A}$ & \\
\hline Carbohydrates & $8.84 \pm 0.03^{A}$ & $6.94 \pm 0.03^{B}$ & \\
\hline \multicolumn{4}{|l|}{ Nutritional } \\
\hline \multicolumn{4}{|l|}{$E A A^{2}(\mathrm{~g} / 100 \mathrm{~g}$ protein) } \\
\hline His & $1.99 \pm 0.04^{\mathrm{A}}$ & $2.01 \pm 0.03^{A}$ & 1.60 \\
\hline Ile & $3.37 \pm 0.03^{A}$ & $3.29 \pm 0.04^{\mathrm{B}}$ & 3.00 \\
\hline Leu & $6.03 \pm 0.03^{A}$ & $6.00 \pm 0.04^{A}$ & 6.10 \\
\hline Lys & $4.63 \pm 0.02^{\mathrm{A}}$ & $4.60 \pm 0.02^{\mathrm{B}}$ & 4.80 \\
\hline Met+Cys & $2.69 \pm 0.03^{A}$ & $2.48 \pm 0.02^{B}$ & 2.30 \\
\hline Phe+Tyr & $5.18 \pm 0.02^{\mathrm{A}}$ & $5.02 \pm 0.03^{B}$ & 4.10 \\
\hline Thr & $2.58 \pm 0.04^{A}$ & $2.51 \pm 0.04^{\mathrm{B}}$ & 2.50 \\
\hline Trp & $1.63 \pm 0.02^{\mathrm{A}}$ & $1.54 \pm 0.05^{\mathrm{B}}$ & 0.66 \\
\hline Val & $4.23 \pm 0.02^{\mathrm{A}}$ & $4.25 \pm 0.04^{A}$ & 4.00 \\
\hline Total & 32.33 & 31.70 & 29.06 \\
\hline EAA Chemical score & 96.45 & 95.83 & \\
\hline Limitant $A A E$ & Lys & Lys & \\
\hline$I V P D^{3}(\%)$ & $77.9^{\mathrm{B}}$ & $84.05^{\mathrm{A}}$ & \\
\hline$C-P E R^{4}$ & $1.70^{\mathrm{B}}$ & $2.15^{\mathrm{A}}$ & \\
\hline
\end{tabular}

1 EAA requirements for children ( 3 years and older), adolescents and adults according to FAO (2013). ${ }^{2} E A A=$ Essential amino acid(s), ${ }^{3}$ IVPD $=$ In vitro protein digestibility (\%) ${ }^{4} \mathrm{C}-P E R=$ Calculated protein efficiency ratio. 
Table 3. Antioxidant activity, total phenolic content, and antihypertensive potential of unprocessed and extruded defatted chia flours.

Tabla 3. Actividad antioxidante, compuestos fenólicos totales y potencial antihipertensivo de harinas de chía desgrasadas sin procesar y extrudida.

\begin{tabular}{|c|c|c|}
\hline Property & $\begin{array}{l}\text { Unprocessed defatted } \\
\text { chia flour } \\
\text { (UDCF) }\end{array}$ & $\begin{array}{c}\text { Optimized } \\
\text { extruded } \\
\text { defatted chia } \\
\text { flour (OEDCF) }\end{array}$ \\
\hline \multicolumn{3}{|l|}{ Antioxidant activity ${ }^{1}$} \\
\hline \multicolumn{3}{|l|}{ ABTS } \\
\hline Free phenolics & $2,965 \pm 133^{B}$ & $4,833 \pm 150^{A}$ \\
\hline Bound phenolics & $11,587 \pm 543^{B}$ & $12,698 \pm 589^{A}$ \\
\hline Total & $14,552 \pm 717^{B}$ & $17,531 \pm 698^{A}$ \\
\hline \multicolumn{3}{|l|}{ ORAC } \\
\hline Free phenolics & $8,456 \pm 230^{\text {B }}$ & $10,781 \pm 198^{A}$ \\
\hline Bound phenolics & $14,268 \pm 392^{B}$ & $15,986 \pm 375^{A}$ \\
\hline Total & $22,724 \pm 612^{B}$ & $26,767 \pm 504^{A}$ \\
\hline \multicolumn{3}{|c|}{ Phenolic compounds ${ }^{2}$} \\
\hline Free phenolics & $248.94 \pm 2.97^{B}$ & $302.44 \pm 4.81^{\mathrm{A}}$ \\
\hline Bound phenolics & $252.32 \pm 4.19^{B}$ & $339.40 \pm 3.61^{A}$ \\
\hline Total & $501.26 \pm 12.70^{B}$ & $641.84 \pm 14.2^{A}$ \\
\hline $\begin{array}{l}\text { Antihypertensive } \\
\text { potential }\left(\mathrm{IC}_{50}\right)^{3}\end{array}$ & $0.51 \pm 0.02^{A}$ & $0.34 \pm 0.01^{\mathrm{B}}$ \\
\hline
\end{tabular}

A-B Means with different superscripts in the same row are significantly different (Duncan, $\mathrm{p} \leq 0.05$ ). ${ }^{1} \mu \mathrm{mol}$ Trolox equivalents (TE) / $100 \mathrm{~g}$ sample, DW.

${ }^{2} \mathrm{mg}$ gallic acid equivalents (GAE) / $100 \mathrm{~g}$ sample, DW.

${ }^{3} \mathrm{mg}$ extract/ $\mathrm{ml}$.

Effect of optimized extrusion process on chemical composition and nutritional properties of defatted chia flour

Table 2 shows protein, lipid and dietary fiber content of unprocessed and optimized extruded defatted chia flours (UDCF, OEDCF). The extrusion process caused slight changes in the chemical composition of defatted chia flours during the production of OEDCF. The essential amino acid (EAA) content of UDCF and OEDCF is shown in Table 2. In general, the EAA content of UDCF and OEDCF were higher than those suggested by FAO (2013) for the requirement of essential amino acids for children (3 years and older), adolescents and adults, except Lys and Leu content, which were slightly below the FAO standard; in both UDCF and OEDCF Lys and Leu were presented as limiting amino acids. The extrusion process caused a slight decrease $(p<0.05)$ in the EAA content of defatted chia flour. Both flours present a high EAA chemical score (95.83-96.45). On the other hand, the extrusion process increased IVPD of defatted chia flour. During food processing by extrusion, both an IVPD increase and an IVPD decrease may occur. This increase of IVPD occurs due to the destruction of labile anti-nutritional factors (lectins, trypsin and chymotrypsin inhibitors) and protein denaturation, as a result of the applied conditions (shearing forces, temperature, and humidity) during processing (Gamel et al., 2006; Montoya-Rodriguez et al., 2015). The decrease of IVPD in extrusion occurs because the components of dietary fiber, phenolic compounds, and the products of the Maillard reaction (reaction carried out between reducing sugars and amino acids of the proteins) can bind to protein, partially unavailing it for its digestion (Reyes-Moreno et al., 2018). However, the increase of IVPD during food processing by extrusion is the most commonly reported phenomenon in literature, which agrees with the results obtained in the present investigation. Results in Table 2 also indicated that C-PER increased during the OEDCF generation. This nutritional parameter was calculated using the IVPD and the EAA composition of the sample, so its increase was mainly due to the increase in IVPD, since the $E A A$ content only slightly decreased.

Gutiérrez-Dorado et al. (2008a) carried out a study to improve the nutritional quality of tortillas, employing as a strategy the use of flours produced by extrusion from high quality protein maize (QPM). In this study, we evaluated nutritionally the protein quality of tortillas obtained by in vitro and in vivo assays. Tortillas produced with extruded QPM flour had an improved amino acid profile and higher IVPD, C-PER, PER, NPR and PDCAAS values than tortillas made from a commercial nixtamalized corn flour (MASECA ${ }^{\mathrm{TM}}$ ). These researchers also reported that tortillas made with extruded QPM flour had higher dietary fiber content than tortillas made with MASECA ${ }^{\mathrm{TM}}$, since, during the flour production by extrusion, all components of the grain were retained, including the pericarp, which is a rich source of fiber. However, the dietary fiber content of the extruded QPM tortillas was slightly lower than that of the tortillas obtained in this research work with the mixture of MASECA ${ }^{\text {TM }}$ and OEDCF $(15.22$ vs. $17.11 \%$, respectively). Comparing our results on protein nutritional evaluation and the extruded QPM tortillas from the aforementioned study, both kinds of tortillas had a similar chemical score of the protein (71 vs 70, respectively), and the limiting amino acid in the tortillas with OEDCF was Lys, while in the tortillas with extruded QPM was Trp. However, although the content of Lys in the tortillas with OEDCF was lower than that of the extruded QPM tortillas, the chemical score of the protein was higher than that of tortillas produced from MASECA ${ }^{\mathrm{TM}}$ flour. Regarding the IVPD and C-PER, tortillas with OEDCF had higher values than the extruded QPM tortillas (IVPD: 83.22 vs 77.40, C-PER: 1.98 vs 1.80, respectively). Another study conducted by Gutierrez-Dorado et al. (2008b), concluded that the PER obtained using IVPD and amino acids underestimated the values obtained in rats, however the absolute differences between the two treatments were similar, indicating that the C-PER technique predicted the same difference observed in the bioassay in rats. They recommend using in vitro techniques as a rapid and accurate indicator of IVPD and PERs in foods.

\section{Effect of extrusion on antioxidant activity (AoxA) and total phenolic compounds (TPC) of defatted chia seeds}

Unprocessed defatted chia seeds (UDCF) had ABTS antioxidant values of 2,965, 11,587, and 14,552 $\mu$ mol Trolox equivalent (TE) / $100 \mathrm{~g}$ sample, and ORAC antioxidant values of 8,456, 14,268, and 22,724 $\mu \mathrm{mol}$ TE / $100 \mathrm{~g}$ sample, to free, bound, and total phenolic compounds, respectively (Table 3). Gómez-Favela et al. (2017) reported similar values of AoxA to free, bound, and total phenolic compounds in chia 
seeds (ABTS: 2,412, 9,843, and 12,255 $\mu \mathrm{mol}$ TE / $100 \mathrm{~g}$ sample, respectively; ORAC: 6961, 12,169, and 19,130 $\mu \mathrm{mol}$ TE / 100 g sample, respectively). Marineli et al. (2014) reported an ORAC antioxidant value $(51,730 \mu \mathrm{mol} T \mathrm{TE} / 100 \mathrm{~g}$ free fraction of defatted sample) in Chilean chia seeds higher than that of UDCF. This difference could be due to several agronomic factors such as soil type, harvesting time, weather conditions, and others, which influence on secondary metabolites in plants, leading to the increase or decrease of phenolic compounds with antioxidant activity and, in this way, to the increase or decrease of the seeds antioxidant activity. The high antioxidant activities in chia seeds could be due to a high content of polyphenolic compounds (Gómez-Favela et al., 2017). The application of the extrusion process to produce OEDCF increased $(p<0.05)$ the AoxA, evaluated by ABTS, and ORAC procedures, by $20.47 \%$ and $17.79 \%$, respectively, when compared to UDCF (Table 3). The AoxA of bound and free phenolic compounds, quantified by ABTS method in defatted chia seeds, increased ( $p<0.05$ ) by $9.58 \%$ and $63.0 \%$, respectively, after extrusion process (Table 3 ). The AoxA of $O E D C F$, evaluated in bound and free phenolics using the ORAC assay, increased by $12.04 \%$ and $27.49 \%$, respectively, when compared to UDCF. This AoxA increase could relate to the release of antioxidant phenolic compounds during the extrusion process, prevention of oxidation of phenolic compounds in the extruded product (by enzymatic inactivation during the processing), and the presence of Maillard reaction products with antioxidant activity (generated during extrusion of raw material that contain amino acids and reducing sugars) (Milán-Carrillo et al., 2012; Espinoza-Moreno et al., 2016). The AoxA mechanism of the melanoidins is based on their ability to trap positively charged electrophilic species, eliminate oxygen radicals or carry out the chelation of metals to form inactive complexes (Delgado-Andrade and Morales, 2005). In addition, TPC increased significantly (21.86\%) during the preparation of OEDCF by extrusion; being bound phenolic compounds the main fraction responsible for the improvement on TPC (Table 3). This increase in TPC may be accountable for the improvement in AoxA of OEDCF, explained above. The extrusion process increases phenolic compounds content due to the destruction of cell walls, release of phenolic compounds, and formation of Maillard reaction products, quantified as phenolic compounds (Espinoza-Moreno et al., 2016). In the literature, it has been reported that melanoidins, like phenolic compounds, react with the Folin-Ciocalteu reagent; in some studies, this method has even been used to indirectly quantify melanoidins (Pérez-Hernández et al., 2013).

\section{Effect of optimized extrusion process on antihyperten- sive potential [inhibition of angiotensin-converting enzyme $(A C E)]$ of phenolic compounds extracted from chia flours}

The anti-hypertensive potential was defined as $I_{50}$ [concentration ( $\mathrm{mg}$ of extract $/ \mathrm{mL}$ ) required to produce an inhibition of $50 \%$ of the ACE activity]. Phenolic compounds extracted from OEDCF had better anti-hypertensive potential (lower $I C_{50}$ value) than the phenolic compounds extracted from UDCF ( 0.34 vs. $0.51 \mathrm{mg}$ extract $/ \mathrm{mL}$, respectively) (Table 3). The benefits of $I C_{50}$ obtained in this research are in concordance with reported results for phenolic extracts of soybean $(0.143-0.160 \mathrm{mg} / \mathrm{mL}$ ) and grape seeds $(0.1-3.5 \mathrm{mg} / \mathrm{L}$ ) (Ademiluyi and Oboh, 2013). The $I C_{50}$ value improvement during the extrusion process of defatted chia seeds could have occurred by release and formation of bioactive compounds (phenolic compounds and Maillard reaction products) with anti-hypertensive potential. As mentioned above, in this research work an increase in the phenolic compounds content occurred during processing of chia by extrusion (Table 3). It has been reported that phenolic compounds (phenolic acids, flavonoids, tannins, stilbenes) inhibit the in vitro ACE activity. The degree of inhibition of the ACE activity depends on the absorption and metabolism of these compounds, and its action mode is closely related with the class (subclass) and the structure of the phenolic compound that is employed (Massaretto et al., 2011; Al-Shukor et al., 2013). According to our results, phenolic compounds present in extruded chia flour, obtained by extrusion process at optimal conditions, could be used as functional food supplements or natural medicines for the treatment of hypertension.

\section{Effect of optimized extruded defatted chia flour (OEDCF) addition on quality of nixtamalized maize tortillas}

The chemical composition, nutritional and nutraceutical properties, and sensory acceptability of tortillas from commercial nixtamalized maize flour (MASECA ${ }^{\mathrm{TM}}$ ) and maize tortillas enriched with optimized extruded defatted chia flour (OEDCF) is shown in Table 4. Tortillas, elaborated with $75 \% \mathrm{MASECA}^{\mathrm{TM}}+25 \%$ OEDCF, had higher protein, lipids, IVPD, C-PER, dietary fiber, and TPC than tortillas elaborated only with MASECA ${ }^{\text {TM }}$ flour. The addition of OEDCF to MASECA ${ }^{\mathrm{TM}}$ flour increased the tortillas nutritional properties. Rendón-Villalobos et al. (2012) evaluated the effects of chia powders supplementation on the physicochemical and sensorial characteristics as well as starch digestibility of tortillas. They used composite flours containing $5 \%, 10 \%, 15 \%$, and $20 \%$ of chia seed flour and corn. In agreement with the present research, they reported that nutritionally, all chia tortillas had significantly higher levels of protein, lipids, and total dietary fiber than the control. Additionally, they observed that the reduced enzymatic starch hydrolysis rate and predicted glycemic index recorded for the chia seed flour-added tortilla indicated slow digestion features. According to these researchers, owing to the increase in the total dietary fiber, lower digestion, and predicted glycemic index values, chia seed flour-added tortilla can be considered as a nutraceutical food. Cortes-Soriano et al. (2016) studied the effect of the addition of nixtamalized oatmeal on the quality of commercial maize tortillas. They made tortillas with mixtures of nixtamalized maize and oat flours (NMF, NOF); the NOF was obtained from the variety Obsidiana, and NMF was the brand MINSA. The mixtures NOF: NMF evaluated were: 10:90, 
Table 4. Chemical composition, nutritional and nutraceutical properties, and sensory acceptability of tortillas from commercial nixtamalized maize flour (MASECA ${ }^{\mathrm{TM}}$ ) and tortillas added with optimized extruded defatted chia flour (MASECA ${ }^{\mathrm{TM}}+$ OEDCF).

Tabla 4. Composición química, propiedades nutricionales y nutracéuticas, y aceptabilidad sensorial de tortillas de harina de maíz nixtamalizado comercial (MASECA ${ }^{\text {MR }}$ ) y tortillas añadidas con harina de chía desgrasada extrudida optimizada (MASECA $\left.{ }^{\mathrm{Mr}}+\mathrm{HCDEO}\right)$.

\begin{tabular}{|c|c|c|c|}
\hline Property & $\begin{array}{c}\text { Tortillas from } \\
\text { MASECA }\end{array}$ & $\begin{array}{c}\text { Tortillas from } \\
\text { MASECA+ } \\
\text { OEDCF }^{1}\end{array}$ & $\begin{array}{c}\mathrm{FAO}^{2} \\
\text { requirements }\end{array}$ \\
\hline \multicolumn{4}{|c|}{ Chemical composition (\%, DW) } \\
\hline Proteins & $8.88 \pm 0.05^{\text {B }}$ & $14.33 \pm 0.13^{A}$ & \\
\hline Lipids & $5.30 \pm 0.02^{A}$ & $5.23 \pm 0.05^{B}$ & \\
\hline \multicolumn{4}{|l|}{ Dietary fiber } \\
\hline Soluble & $1.37 \pm 0.06^{\mathrm{B}}$ & $2.85 \pm 0.09^{A}$ & \\
\hline Insoluble & $4.70 \pm 0.10^{B}$ & $14.26 \pm 0.13^{\mathrm{A}}$ & \\
\hline Total & $6.07 \pm 0.12^{B}$ & $17.11 \pm 0.18^{\mathrm{A}}$ & \\
\hline \multicolumn{4}{|l|}{ Nutritional } \\
\hline \multicolumn{4}{|l|}{$E A A^{3}$ (g/100 g protein) } \\
\hline $\mathrm{His}$ & $2.49 \pm 0.02^{A}$ & $2.39 \pm 0.03^{B}$ & 1.60 \\
\hline Ile & $2.83 \pm 0.03^{B}$ & $3.01 \pm 0.04^{\mathrm{A}}$ & 3.00 \\
\hline Leu & $11.94 \pm 0.06^{A}$ & $11.58 \pm 0.05^{B}$ & 6.10 \\
\hline Lys & $2.44 \pm 0.04^{B}$ & $3.42 \pm 0.05^{\mathrm{A}}$ & 4.80 \\
\hline Met+Cys & $3.39 \pm 0.03^{A}$ & $3.20 \pm 0.02^{B}$ & 2.30 \\
\hline Phe+Tyr & $7.58 \pm 0.05^{A}$ & $6.94 \pm 0.03^{B}$ & 4.10 \\
\hline Thr & $2.70 \pm 0.02^{A}$ & $2.67 \pm 0.04^{A}$ & 2.50 \\
\hline Trp & $0.56 \pm 0.04^{B}$ & $0.79 \pm 0.05^{A}$ & 0.66 \\
\hline Val & $4.23 \pm 0.05^{A}$ & $4.19 \pm 0.04^{A}$ & 4.00 \\
\hline Total & 38.16 & 38.19 & 29.06 \\
\hline Chemical score & 50.83 & 71.25 & \\
\hline Limitant $E A A$ & Lys & Lys & \\
\hline $\begin{array}{l}\text { In vitro protein } \\
\text { digestibility (\%) }\end{array}$ & $75.90 \pm 0.21^{\mathrm{B}}$ & $83.22 \pm 0.20^{A}$ & \\
\hline C-PER ${ }^{4}$ & $1.12 \pm 0.06^{\mathrm{B}}$ & $1.98 \pm 0.05^{A}$ & \\
\hline \multicolumn{4}{|l|}{ Nutraceutical } \\
\hline Antioxidant activity ${ }^{5}$ & $5,985 \pm 246^{B}$ & $12,499 \pm 438^{A}$ & \\
\hline $\begin{array}{l}\text { Antihypertensive } \\
\text { potential }\left(/ C_{50}\right)^{6}\end{array}$ & Non detected & 0.67 & \\
\hline \multicolumn{4}{|l|}{ Sensory } \\
\hline Acceptability ${ }^{7}$ & $8.5^{\mathrm{A}}$ & $8.3^{A}$ & \\
\hline Puffing & $3^{A}$ & $3^{A}$ & \\
\hline Rollability & $5^{A}$ & $5^{A}$ & \\
\hline
\end{tabular}

${ }^{A-B}$ Means with different superscript letters in the same row are significantly different (Duncan, $\mathrm{p}<0.05$ ).

${ }^{1}$ Tortillas elaborated with $75 \%$ MASECA ${ }^{\text {TM }}$ flour $+25 \%$ Optimized extruded defatted chia flour (OEDCF).

${ }^{2} \boldsymbol{E} \boldsymbol{A} \boldsymbol{A}$ requirements for children (3 years and older), adolescents and adults according to FAO (2013).

${ }^{3} \boldsymbol{E A} \boldsymbol{A}=$ Essential amino acid

${ }^{4}$ C-PER $=$ Calculated protein efficiency ratio.

${ }^{5} \boldsymbol{\mu m o l}$ Trolox equivalents (TE) / $100 \mathrm{~g}$ sample, DW.

${ }^{6} \mathrm{mg}$ extract/ $\mathrm{mL}$. ${ }^{7}$ Degree of liking/disliking using a 9-category hedonic scale ( 1 = dislike extremely to $9=$ like extremely).
$20: 80,30: 70$, and 40:60, respectively. The quality of the tortilla was measured based on the diameter $(\mathrm{cm})$, thickness $(\mathrm{mm})$, the weight of the tortilla hot and cold $(\mathrm{g})$, the rollability, the performance of the hot and cold tortilla and colorimetry. Additionally, compositional analysis and sensory evaluation of tortillas showed that the 40:60 mixture had a high protein and fiber content, but less acceptability; while those made with 10:90 and 20:80 had the highest protein content, and better acceptability, taste, and texture compared to tortillas from NMF.

Tortillas, elaborated with a mixture of MASECA ${ }^{\mathrm{TM}}$ flour and OEDCF, had higher antioxidant activity (ORAC: 12,499 vs $5,985 \mu \mathrm{mol}$ TE/100 g, DW), and better anti-hypertensive potential $(0.67 \mathrm{mg}$ extract $/ \mathrm{mL}$ vs ND) than tortillas elaborated only with MASECA ${ }^{\mathrm{TM}}$ flour (Table 4). The extruded chia flour, obtained by extrusion process under optimal conditions, could be used as functional food supplements or natural medicine for hypertension treatment. The improvement of AoxA and anti-hypertensive potential during the extrusion process of defatted chia flour could have occurred by release and formation of bioactive compounds (phenolic compounds and Maillard reaction products) with antioxidant and anti-hypertensive potential. Phenolic compounds (Phenolic acids, flavonoids, tannins, stilbenes) inhibit the in vitro ACE activity (Massaretto et al., 2011; Al-Shukor et al., 2013).

The newly developed tortilla, elaborated with $75 \%$ MASECA $^{\text {TM }}$ flour+25\% OEDCF could represent a valuable staple in improving the nutritional value of the original food product.

\section{CONCLUSIONS}

The best combination of process variables to produce optimized extruded defatted chia flour with maximum antioxidant activity, total phenolic content, and in vitro protein digestibility was $\mathrm{ET}=147{ }^{\circ} \mathrm{C} / \mathrm{SS}=237 \mathrm{rpm}$. The addition of optimized extruded defatted chia flour to the nixtamalized maize tortillas caused an increase in the quantity and nutritional quality of the protein, as well as an increase in its dietary fiber content. In addition, tortillas added with chia had a higher content of total phenolic compounds, and antioxidant and antihypertensive activity than tortillas produced only from nixtamalized maize flour. The use of extruded chia flour in the preparation of nixtamalized maize tortillas may have a positive effect on the healthy status of people from countries where these products are widely consumed.

\section{ACKNOWLEDGEMENT}

This work was financially supported by Consejo Nacional de Ciencia y Tecnología (CONACYT), Ciencia Básica Convocatoria 2014 (No. 241090) and Programa de Fomento y Apoyo a Proyectos de Investigación (PROFAPI 2015), of Universidad Autónoma de Sinaloa. 


\section{REFERENCES}

Acevedo-Pacheco, L. and Serna-Saldívar, S.O. 2016. In vivo protein quality of selected cereal-based staple foods enriched with soybean proteins. Food and Nutrition Research, 60:313-382.

Ademiluyi, A.O. and Oboh, G. 2013. Soybean phenolic-rich extracts inhibit key enzymes linked to type 2 diabetes (a-amylase and a-glucosidase) and hypertension (angiotensin I converting enzyme) in vitro. Experimental and Toxicologic Pathology, 65:305-309.

Al-Shukor, N., Van-Camp, J., Gonzales, G.B., Staljanssens, D., Struijs, K., Zotti, M.J., Raes, K. and Smagghe, G. 2013. Angiotensin-converting enzyme inhibitory effects by plant phenolic compounds: a study of structure-activity relationships. Journal of Agricultural and Food Chemistry, 61:11832-11839.

Amaya-Guerra, C.A., Alanis-Guzman, M.G. and Serna-Saldívar, S.O. 2004. Effects of soybean fortification on protein quality of tortilla-based diet from regular and quality protein maize. Plant Foods for Human Nutrition, 59:45-50.

AOAC. 1999. Official Methods of Analysis $16^{\text {th }}$ ed. Harla, Association of Official Analytical Chemists, St. Paul, USA

Argüelles-López, O.D., Reyes-Moreno, C., Gutiérrez-Dorado, R., Sánchez-Osuna, M.F., López-Cervantes, J., CuevasRodríguez, E.O., Milán-Carrillo, J. and Perales-Sánchez, J.X.K. 2018. Functional beverages elaborated from amaranth and chia flours processed by germination and extrusion. Biotecnia, XX: 135-145.

Awika, J.M., Rooney, L.W., Wu, X., Prior, R.L. and Cisneros-Zevallos, L. 2003. Screening methods to measure antioxidant activity of sorghum (Sorghum bicolor) and sorghum products. Journal of Agricultural and Food Chemistry, 51:6657-6662.

Bedolla, S. and Rooney, L.W. 1984. Characteristics of U.S. and Mexican instant maize flour for tortilla and snack preparation. Cereal Foods World, 29:732-735.

Bochicchio, R., Philips, T.D., Lovelli, S., Labella, R., Galgano, F., Di-Marisco, A., Perniola, M. and Amato, M. 2015. Innovative Crop Productions for Healthy Food: The Case of Chia (Salvia hispanica L.). En:The Sustainability of Agro-Food and Natural Resource Systems in the Mediterranean Basin, Vastola A (ed), Springer, Rome, Italy

Chuck-Hernández, C., Perez-Carrillo, E., Soria-Hernández, C. and Serna-Saldívar, S.O. 2015. Functionality and organoleptic properties of maize tortillas enriched with five different soybean proteins. Cereal Chemistry, 92:341-349.

Corrales-Bañuelos, A.B., Cuevas-Rodríguez, E.O., Gutiérrez-Uribe, J.A., Milán-Noris, E.M., Reyes-Moreno, C., Milán-Carrillo J, and Mora-Rochín A. 2016. Carotenoid composition and antioxidant activity of tortillas elaborated from pigmented maize landrace by traditional nixtamalization or lime cooking extrusion process, Journal of Cereal Science, 69:6470.

Cortes-Soriano, I., Buendía-González, M.O., Palacios-Rojas, N., Martínez-Cruz, E., Villaseñor-Mir, H.E. and Santa-Rosa, R.H. 2016. Quality assessment corn tortilla added with oatmeal (Avena sativa L.) nixtamalized. Revista Mexicana de Ciencias Agrícolas, 7:1715-1725.

Delgado-Andrade, C. and Morales, F. J. 2005. Unraveling the contribution of melanoidins to the antioxidant activity of coffee brews. Journal of Agricultural and Food Chemistry, 53:1403-1407.
Espinoza-Moreno, R.J., Reyes-Moreno, C., Milán-Carrillo, J., López-Valenzuela, J.A., Paredes-López, O. and GutiérrezDorado, R. 2016. Healthy ready-to-eat expanded snack with high nutritional and antioxidant value produced from whole amarantin transgenic maize and common black bean. Plant Foods for Human Nutrition, 71:218-224.

FAO. 2013. Findings and Recommendations of the 2011 FAO Expert Consultation on Protein Quality Evaluation in Human Nutrition. In: "Dietary Protein Quality Evaluation in Human Nutrition: Report of an FAO Expert Consultation." FAO Food and Nutrition Paper 92. Food and Agriculture Organization of the United Nations, Rome, Italy, chapter 4, pp. 29.

Gamel, T.H., Linssen, J.P., Mesallam, A.S., Damu, A.A. and Shekib, L.A. 2006. Effect of seed treatments on the chemical composition of two amaranth species. Oil, sugars, minerals, and vitamins. Journal of the Science of Food and Agriculture, 80:82-89.

Grajales-García, E.M., Osorio-Díaz, P., Goñi, l., Hervert-Hernández, D., Guzmán-Maldonado, S.H. and Bello-Pérez, L.A. 2012. Chemical composition, starch digestibility and antioxidant capacity of tortilla made with a blend of quality protein maize and black bean. International Journal of Molecular Science, 13:286-301.

Gómez-Favela, M.A., Gutiérrez-Dorado, R., Cuevas-Rodríguez, E.O., Canizalez-Román, V.A., León-Sicairos, C.R., MilánCarrillo, J. and Reyes-Moreno, C. 2017. Improvement of chia seeds with antioxidant activity, GABA, essential amino acids, and dietary fiber by controlled germination bioprocess. Plant Foods for Human Nutrition, 72:1-8.

Gutiérrez-Dorado, R., Ayala-Rodríguez, A.E., Milán-Carrillo, J., López-Cervantes, J., Garzón-Tiznado, J.A., López-Valenzuela, J.A., Paredes-López, O. and Reyes-Moreno C. 2008a. Technological and Nutritional Properties of Flours and Tortillas from Nixtamalized and Extruded Quality Protein Maize (Zea mays L.). Cereal Chemistry, 85:808-816.

Gutiérrez-Dorado, R., Cárdenas-Valenzuela, O.G., AlarcónValdez, C., Garzón-Tiznado, J.A., Milán-Carrillo, J., ArmientaAldana, E. and Reyes-Moreno, C. 2008b. Alimento para niños preparado con harinas de maíz de calidad proteínica y garbanzo extruidos. Interciencia, 33:868-874.

Hirth, M., Preib, R., Mayer-Miebach, E. and Schuchmann, H.P. 2015. Influence of HTST extrusion cooking process parameters on the stability of anthocyanins, procyanidins and hydroxycinnamic acids as the main bioactive chokeberry polyphenols. LWT - Food Science and Technology, 62:511516.

Kaur, C. and Kapoor, HC. 2001. Antioxidants in fruits and vegetables - the millennium's health. International Journal of Food Science and Technology, 36:703-725

Korus, J., Gumul, D. and Czechowska, K. 2007. Effect of extrusion on the phenolic composition and antioxidant activity of dry beans of Phaseolus vulgaris L. Food Technology and Biotechnology, 45:139-146.

Marineli, R.S., Moraes, É.A., Lenquiste, S.A., Godoy, A.T., Eberlin, M.N. and Maróstica, M.R.Jr. 2014. Chemical characterization and antioxidant potential of Chilean chia seeds and oil (Salvia hispanica L.). LWT - Food Science and Technology, 59:13041310.

Martínez-Cruz, O. and Paredes-López, O. 2014. Phytochemical profile and nutraceutical potential of chia seeds (Salvia hispanica L.) by ultra-high-performance liquid chromatography. Journal of Chromatography A, 1346:43-48. 
Massaretto, I.L., Madureira-Alves, M.F., Mussi de Mira, N.V., Carmona, A.K. and Lanfer-Marquez, U.M. 2011. Phenolic compounds in raw and cooked rice (Oryza sativa L.) and their inhibitory effect on the activity of angiotensin I-converting enzyme. Journal of Cereal Science, 54:263-240.

Milán-Carrillo, J., Gutiérrez-Dorado, R, Perales-Sánchez, J.X.K., Cuevas-Rodríguez E.O., Ramírez-Wong, R, and ReyesMoreno, C. 2006. The optimization of the extrusion process when using maize flour with a modified amino acid profile for making tortillas. International Journal Food Science and Technology, 41:727-736

Milán-Carrillo, J., Montoya-Rodríguez, A., Gutiérrez-Dorado, R., Perales-Sánchez, J.X.K. and Reyes-Moreno, C. 2012. Optimization of the extrusion process for producing high antioxidant instant amaranth (Amaranthus hypochondriacus L) flour using response surface methodology. Applied Mathematics, 3:1516-1525.

Montoya-Rodríguez, A., Milán-Carrillo, J., Reyes-Moreno, C. and González de Mejía, E. 2015. Characterization of peptides found in unprocessed and extruded amaranth (Amaranthus hypochondriacus) pepsin/pancreatin hydrolysates. International Journal of Molecular Sciences, 16:8536-8554.

Mora-Rochín, S., Gutiérrez-Uribe, J.A., Serna-Saldívar, S.O., Sánchez-Peña, P., Reyes-Moreno, C. and Milán-Carrillo, J. 2010. Phenolic content and antioxidant activity of tortillas produced from pigmented maize processed by conventional nixtamalization or extrusion cooking. Journal of Cereal Science, 52:502-508.

Orona-Tamayo, D., Valverde, M.E. and Paredes-López, O. 2016. Chia - The New Golden Seed for the 21st Century: Nutraceutical Properties and Technological Uses. In: "Sustainable Protein Sources", $1^{\text {st }}$ edition, Nadathyr S (ed), Elsevier Publishers, Chapter 17, pp 265-281 doi: 10.1016/ B978-0-12-802778-3.00017-2.

Pérez-Hernández L. M, Chávez-Quiroz, K., Medina-Juárez, L. Á. and Gámez-Meza, N. 2013. Phenolic compounds, melanoidins, and antioxidant activity of green coffee bean and processed coffee from Coffea arabica and Coffea canephora species. Biotecnia, 15:51-56.

Re, R., Pellegrini, N., Proteggente, A., Pannala, A., Yang, M. and Rice-Evans, C. 1999. Antioxidant activity applying an improved ABTS radical cation decolorization assay. Free Radical Biology and Medicine, 26:1231-1237.

Rendón-Villalobos, R., Ortiz-Sanchez, A., Solorza-Feria, J. and Trujillo-Hernandez, C.A. 2012. Formulation, physicochemical, nutritional and sensorial evaluation of corn tortillas supplemented with chia seed (Salvia hispanica L.). Czech Journal of Food Science, 30:118-125.
Reyes-Moreno, C., Reyes-Fernández, P.C., Cuevas-Rodríguez, E.O., Milán-Carrillo, J. and Mora-Rochín, S. 2018. Changes in Nutritional Properties and Bioactive Compounds in Cereals During Extrusion Cooking. En: Extrusion of Metals, Polymers, and Food Products. [Consultado 18 Enero 2019] Disponible en: http://www.intechopen.com/books/ extrusion-of-metals-polymersand-food-products http:// dx.doi.org/10.5772/intechopen.68753

Salas-López, F., Gutiérrez-Dorado, R., Milán-Carrillo, J., CuevasRodríguez, E.O., Canizalez-Román, V.A., León-Sicairos, C.R. and Reyes-Moreno, C. 2018. Nutritional and antioxidant potential of a desert underutilized legume tepary bean (Phaseolus acutifolius). Optimization of germination bioprocess. Food Science and Technology (Campinas). On line. doi.org/10.1590/fst.25316.

Salazar-Vega, I.M., Segura-Campos, M.R., Chel-Guerrero., L.A. and Betancur-Ancona, D.A. 2012. Antihypertensive and Antioxidant Effects of Functional Foods Containing Chia (Salvia hispanica) Protein Hydrolysates. En Scientific, Health and Social Aspects of the Food Industry. Valdez B (ed.), InTech. Disponible en: http://www.intechopen.com/books/ scientific-health-and-social-aspectsof-the-food industry/ antihypertensive-and-antioxidant-effects-of-functionalfoods-containing-chia-salviahispanica-protei

Sarawong, C., Schoenlechner, R., Sekiguchi, K., Berghofer, E. and Ng, P.K. 2014. Effect of extrusion cooking on the physicochemical properties, resistant starch, phenolic content and antioxidant capacities of green banana flour. Food Chemistry, 143:33-39.

Treviño-Mejía, D., Luna-Vital, D.A., Gaytán-Martínez, M., Mendoza, S. and Loarca-Piña, G. 2016. Fortification of commercial nixtamalized maize (Zea mays $\mathrm{L}$ ) with common bean (Phaseolus vulgaris L) increased the nutritional and nutraceutical content of tortillas without modifying sensory properties. Journal of Food Quality, 39:569-579.

Ullah, R., Nadeem, M., Khalique, A., Imran, M., Mehmood, S., Javid, A. and Hussain, J. 2015. Nutritional and therapeutic perspectives of Chia (Salvia hispanica L.): A review. Journal of Food Science and Technology, 53:1750-1758.

Valdivia-López, M.A. and Tecante, A. 2015. Chia (Salvia hispanica): A review of native Mexican seed and its nutritional and functional properties. Advances in Food and Nutrition Research, 75:53-75.

Vázquez-Rodríguez, J.A., Amaya-Guerra, C.A., Báez-González, J.G., Nuñez-González, M.A. and Figueroa-Cárdenas, J.D. 2013. Study of the fortification with bean and amaranth flours in nixtamalized maize tortilla. CyTA - Journal of Food, 11:62-66. 